DOI: $10.26907 / 2311-2042-2019-13-2-154-159$

\title{
ON THE BIRTH CENTENARY OF THE OUTSTANDING PAINTER HARIS YAKUPOV
}

\author{
Mikhail Konstantinovich Yao, \\ Kazan Federal University, \\ 18 Kremlyovskaya Str., Kazan, 420008, Russian Federation, \\ Mihail.Yao@kpfu.ru. \\ Juliana Gennadievna Emanova, \\ Kazan Federal University, \\ 18 Kremlyovskaya Str., Kazan, 420008, Russian Federation, \\ emanova-yao@mail.ru
}

Haris Abdrakhmanovich Yakupov (1919-2010) was an outstanding Tatar and Russian painter, graphic artist, illustrator, People's Artist of the RSFSR and the USSR, full member of the Russian Academy of Arts, holder of many orders and medals, laureate of the Stalin Prize of the Third Degree (1951), the State Prize of the RSFSR named after I. E. Repin (1976), the State Prize of the Tatar Autonomous Soviet Socialist Republic named after G. Tukay (1958). He was the author of paintings devoted to the history and culture of the Tatar people, a master of historical and everyday genres, portraits and still lifes.

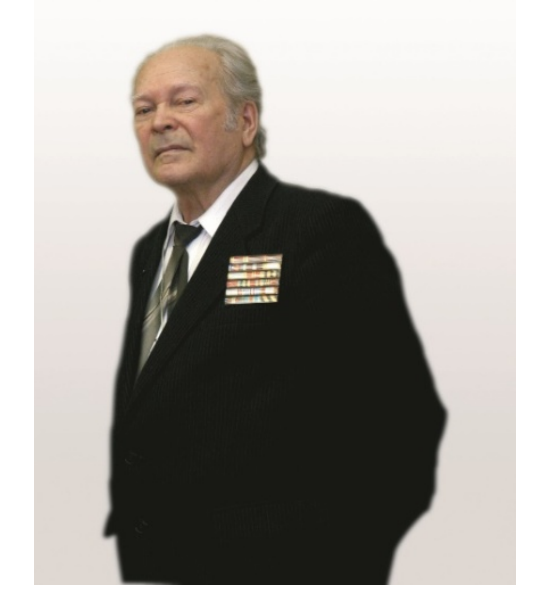

Харис Габдрахман улы Якупов (1919-2010) - күренекле татар рәссамы, график, иллюстратор, РСФСР Һәм СССР ның халык рәссамы, Россия сәнгать Академиясеның хакыйки әгъзасы, бик күп орденнар һәм и медальләр иясе, өченче дәрәжә Сталин премиясе (1951), РСФСРның И. Е. Репин исемендәге Дәүләт премиясе (1976), Татарстан Республикасының Габдулла Тукай исемендәге Дәүләт примиясе лауреаты (1958), татар халкының тарихы hәм мәдәниятенә багышлан картиналар авторы, портрет һәм натюрморт остасы.
Харис Абдрахманович Якупов (1919-2010) - выдающийся татарский и российский живописец, график, иллюстратор, народный художник РСФСР и СССР, действительный член Российской Академии художеств, кавалер многих орденов и медалей, лауреат Сталинской премии третьей степени (1951), Государственной премии РСФСР имени И. Е. Репина (1976), Государственной премии Татарской АССР им. Г. Тукая (1958), автор полотен, посвященных истории и культуре татарского народа, мастер исторического и бытового жанра, портрета и натюрморта.
December 23, 2019, marks the birth centenary of artist Haris Abdrakhmanovich Yakupov. His life story is the history of fine arts in the Republic of Tatarstan. A hundred years. The gallery of images depicting this century is probably the most extensive and controversial. As time passed, we can say that Haris Yakupov occupies a worthy place in this gallery. Many artists captured the milestones of the Soviet country in their own way. Haris Yakupov was working at a certain point in history when the professional art of the Tatar people was formed. It is symbolic that our hero was actually the same age 
as his republic, which was formed on May 27, 1920. Haris Yakupov himself said that since childhood he had observed the traditional lifestyle of the Tatar craft population from Zakabanye. These observations later found their reflection in his work. After graduating from the Kazan Art College in 1940, Yakupov, like many representatives of his generation, entered life wearing a military uniform. He joined World War II exactly one month after it broke out, on July 22, 1941 - and went all the way from Moscow to Prague, so he knew the war firsthand, as he described it in many graphic works and paintings.

In his memoirs, Haris Yakupov tells how later he was admitted to the sanctum sanctorum of the country, the Moscow Kremlin, to paint his contest work: for its composition, he needed to paint the internal appearance of the Kremlin. He was accompanied by an armed guard, vigilantly watching every move of the artist. The former front-line soldier Yakupov told the guard that he shouldn't try to frighten him with a gun, since he himself used to carry the same one for four years running. Yakupov came back from the war with military awards. The young front-line soldier was awarded the medal "For Military Merit", the Order of the Red Star, the Order of the Patriotic War II of the Second Degree (We all sought to win). There was another battle trophy - more than two hundred and fifty sketches made by him at the places of the ongoing battles. Later, they would both provide a basis for his future works and present an interest as talented graphic works.

Yakupov's early period of work, from the late 1940 s, was the time when his big talent developed, immediately attracting attention. He won a number of difficult all-Union competitions. The work of Haris Yakupov was noticed by the recognized masters of Soviet art: Arkady Plastov, perhaps the most outstanding artist of the country, highly appreciated his work. In 1946, Yakupov had an internship at "Vsekokhudozhnik" Moscow Central Studio of Boris Johanson, the very one who painted "Interrogation of the Communists" in 1933, which became a classic of socialist realism.

In 1947, Haris Yakupov joined "The Union of Artists", and in 1951, at the age of thirty, he became chairman of the Union of Artists of Tataria [Chervonnaia]. Haris Yakupov remained in office for over twenty years, until 1975. During this time, he was far from being just the formal head of the creative association of Tatar artists. Under him, the Tatarstan Union of Artists became one of the leading and one of the largest unions in the USSR. The opening of the Union's exhibition hall was the event of republican significance. The zonal art exhibitions "The Big Volga" were held. The fact that Yakupov was first elected a corresponding member of the Academy of Arts, and later, in 1997, a full member of the Russian Academy of Arts, was an indicator of the significance of his contribution to the development of national art. As effective was his activity as the head of the creative workshop at the Academy of Arts, this creative graduate school of young artists. In the course of thirty years, this workshop brought up such dissimilar artists as Shamil Shaydullin, Zufar Gimaev, Farid Yakupov, Stanislav Slesarsky, as well as other interesting, original painters.

Having come to art in the post-war1950s, the period which was characterized by a detailed depiction of the plot, fact, and event, Haris Yakupov painted using the language of his time. His art is figurative, the details are thoroughly reproduced, his compositions resembling theatrical stage scenes. However, the young author managed to capture the ideological content of his era. As early as in 1951, he achieved unprecedented success: together with Lotfulla Fattakhov, he received the third-degree Stalin Prize for the painting "Signing a Decree on the Formation of the Tatar Autonomous Soviet Socialist Republic". The plot and the skill of execution, characterizing this work, were greatly appreciated by the public. The picture shows the moment of signing the Decree on the formation of the Tatar Autonomous Soviet Socialist Republic. Its characters, surrounded by the representatives of the Tatar people, are M. Kalinin, the chairman of the All-Russian Central Executive Committee; I. V. Stalin, a member of the Revolutionary Military Council of the RSFSR; V. Ulyanov (Lenin), the chairman of the Council of People's Commissars.

Using the same manner of painting, but with a greater emotional stress, Yakupov executes another, no less resonant picture "Before the Verdict (Musa Jalil)" (1950-1954, the Museum of Fine Arts of the Republic of Tatarstan). In the best traditions of socialist realism, the artist captured the moral feat of the hero poet, whom he, as a teenager, had seen in 1930s with his own eyes.

Yakupov's manner of painting changed throughout his career. The changing times required new heroes and new forms of art. The author's figurative world also underwent changes. In the 1960s and $80 \mathrm{~s}$, the artist's manner shifted from detailed drawings to more generalized, collective, and monumental images. In that period, the national 
originality of the author's creative manner was clearly seen in the color and composition of his paintings. The main character of his paintings was a generalized image of his time - a simple person whose hands create a new peaceful life. His characters were oil workers, builders of the KamAZ auto giant, and village workers - milkmaids, shepherds, and combine harvesters. The gallery of images of that time included such works as "Strong People" (1964), "The Gold of Tataria" (1974), "Chelninsky Beauties" (1975) and many others.

The theme of the war, disclosed by Yakupov in his frontline sketches, ran through his lifetime creative work. The images of paintings on the war theme were deeply felt by the author. An example is the triptych "A Flight to Freedom" (1964-1971), dedicated to the feat of Senior Lieutenant Mikhail Devyatayev, a fighter pilot, the Hero of the Soviet Union, who was able to escape from a Nazi concentration camp piloting a taken over bomber. The artist and his hero were almost the same age, partly why H. Yakupov so deeply felt the theme of this triptych.

The confessional painting "The Artist. Frontline Roads "(1985) is like a window taking you to the past. This is his self-portrait, a certain look at himself and his difficult front-line youth after forty years had passed.

In Haris Yakupov's legacy, there is a work connected with the history of the University. This is a big picture "Kazan Students. The Year of 1887" [Tatarskii entsiklopedicheskii slovar', p. 683]. The author worked on it for almost ten years. Its creation was timed to coincide with the centennial of the student gathering, in which V. Ulyanov, a first-year student of the law faculty, was directly involved. This panoramic painting depicts a dramatic clash between the university administration and students, demanding reforms in university life. With historical meticulousness the artist reproduced the interior details of the Assembly Hall and the elements of the characters' clothing: a portrait of the emperor, a chandelier, student jackets and an overturned Viennese chair. It is interesting to note that the creative reconstruction of the hall, made by Haris Yakupov in the late 1970s, is close to the scientifically restored interior of the "Imperial Assembly Hall", which was made much later, at the present time.

Another topic worthy of attention is the union of art and poetry. If the painting "Before the Verdict" is devoted primarily to the poet Musa Jalil's feat, the triptych "In Memory of Gabdulla Tukay" (2000) is a visual incarnation of Tukay's poetry in painting. This is a story allegorically depicting the figurative world of the poet.

The latest exhibitions of the artist introduced us to the intimate part of his works. Here, Haris Yakupov presents himself as a talented multifaceted painter and lyrical artist. Quite a number of portrait images pass in front of the viewer. These are the artist's relatives and friends, and simply his contemporaries.

Haris Yakupov strongly felt kinship with nature. His still lifes, depicting simple things, are distinguished by a wonderful performance maestry.

As for the originality of the painter, it should be noted that his art organically combined the trends and plots of time with national expressiveness. The national element in the art of the Tatar artist Haris Yakupov manifested itself primarily in the decorative bright color spots originating from folk decorative and applied art and his tendency towards monumental flatness of composition. The characters of the artist's paintings, like the details of the national costume, are distributed in large spots along the plane of the canvas, thereby creating a bright, positive imaginative solution. It is the positive sound of creativity that is the main content of his art.

The artist was understood and accepted by his contemporaries. In the history of the republic it is difficult to name another cultural figure who would receive the same attention. Haris Yakupov, in addition to the already mentioned military awards, was awarded the highest orders of the USSR - the Orders of Lenin, Friendship of Peoples, the "Badge of Honor", "For Merit to the Fatherland" 4th degree, "For Merit to the Republic of Tatarstan". In addition to the Stalin Prize of 1951, in 1976, he was awarded the State Prize of the RSFSR named after I. E. Repin for his paintings "Chelninsky Beauties" and "Advanced Breeders - Shepherds N. Ziganshin, Sh. and G. Shakirov." In 1958, H. Yakupov and L. Fattakhov received the Republican Prize of the Tatar Autonomous Soviet Socialist Republic named after G. Tukay for their illustrations to the book of Tatar folk tales.

He was awarded the title of People's Artist of the RSFSR in 1963, and in 1980, Yakupov received the highest honorary title of the country: "People's Artist of the USSR".

From 1971 to 1974, Yakupov combined his creative work with the public activities of a deputy of the Supreme Soviet of the USSR.

The whole life of the artist was inextricably linked with the fate of his country, its history, val- 
ues and culture. All the creative work of the painter suggests that he was worthy of his destiny and the grateful memory of posterity.

\section{References}

Chervonnaia, S. M. Kharis Iakupov [Kharis Yakupov]. 160 p. Leningrad, Khudozhnik RSFSR. (In Russian)
My vse stremilis' $k$ pobede... Iz frontovykh al'bomov Kharisa Iakupova (2015) [We All Strove for Victory ... From the Front-Line Albums of Haris Yakupov]. Al'bom-katalog. 176 p. Kazan, Zaman, il. (In Russian)

Tatarskii entsiklopedicheskii slovar' (1998) [Tatar Encyclopedic Dictionary]. Pod red. M. Kh. Khasanova. 703 p. Kazan, Institut Tatarskoi entsiklopedii AN RT. (In Russian)

\title{
К 100-ЛЕТИЮ СО ДНЯ РОЖДЕНИЯ ВЫДАЮЩЕГОСЯ ЖИВОПИСЦА ХАРИСА ЯКУПОВА
}

\author{
Михаил Константинович Яо, \\ Казанский федеральный университет, \\ Россия, 420008, г. Казань, ул. Кремлевская, д. 18, \\ Mihail.Yao@kpfu.ru. \\ Юлиана Геннадьевна Еманова, \\ Казанский федеральный университет, \\ Россия, 420008, г. Казань, ул. Кремлевская, д. 18, \\ emanova-yao@mail.ru.
}

23 декабря 2019 года исполняется 100 лет со дня рождения художника Хариса Абдрахмановича Якупова. Век. Его история жизни - история изобразительного искусства Республики Татарстан. Галерея образов этого столетия, наверное, самая обширная и противоречивая. С высоты времени можно сказать, что Харис Якупов занимает в этой галерее свое достойное место. Многие художники по-своему запечатлевали вехи советской страны. Харис Якупов попал в ту точку истории, когда шел процесс становления профессионального изобразительного искусства татарского народа. Символично, что наш герой фактически ровесник своей республики, образовавшейся 27 мая 1920 года. Сам Харис Якупов рассказывал, что с детства наблюдал традиционный жизненный уклад татарского ремесленного населения Закабанья. Эти наблюдения позднее отразились в его творчестве. Закончив в 1940 году Казанское художественное училище, Якупов, как и многие представители его поколения, вступил в жизнь в гимнастерке призывника. Он встретил Великую Отечественную войну ровно через месяц после ее начала - 22 июля 1941 года - и прошел весь путь войны от Москвы до Праги, так что войну он познал не понаслышке, о чем и рассказал во многих графических и живописных работах.

В своих воспоминаниях Харис Якупов рассказывает, как позднее для написания конкурс- ной работы он был допущен в святая святых страны - Московский Кремль, чтобы написать необходимый для композиции внутренний вид кремля. Его сопровождал строгий охранник с автоматом, зорко следящий за каждым действием художника. Фронтовик Якупов сказал ему, что не стоит пугать его автоматом, так как он сам носил такой же четыре года, не снимая. C фронта Якупов пришел кавалером боевых наград. Молодой фронтовик был награжден медалью «За боевые заслуги», орденом Красной Звезды, орденом Отечественной войны II степени [Мы все стремились к победе]. Был еще один боевой трофей - более двухсот пятидесяти зарисовок, сделанных им на местах проходивших боев. Позднее они не только станут материалом для будущих работ, но и сами по себе вызовут интерес как талантливые графические произведения.

Ранний период его творчества, начавшийся в конце1940-х годов, можно рассматривать как время становления нового крупного таланта, сразу обратившего на себя внимание. Он побеждает в сложных всесоюзных конкурсах. Творчество Хариса Якупова привлекло внимание признанных мастеров советского искусства, о его работах высоко отзывался едва ли не самый выдающийся художник страны того времени Аркадий Пластов. В 1946 году Якупов стажировался в московской Центральной студии «Всекохудожник» Бориса Йогансона - того са- 
мого, который написал в 1933 году картину «Допрос коммуниста», ставшую классикой социалистического реализма.

В 1947 году Харис Якупов вступает в «Союз художников», а в 1951 году, в тридцать с небольшим лет, он становится председателем Союза художников Татарии [Червонная]. На этом выборном посту Харис Якупов оставался свыше двадцати лет, до 1975 года. За это время он был далеко не формальным главой творческого объединения татарских художников. При нем Союз художников Татарстана стал одним из ведущих и самых крупных союзов в СССР. Республиканским событием стало открытие выставочного зала союза. Стали проводится зональные выставки искусства «Большая Волга». Само избрание Якупова сначала членомкорреспондентом Академии Художеств, a позднее, в 1997 году, действительным членом Российской академии художеств является показателем значимости его вклада в развитие национального искусства. Также эффективна была его деятельность в качестве руководителя творческой мастерской Академии Художеств этой творческой аспирантуры молодых художников. За тридцатилетнюю деятельность эта мастерская воспитала таких не похожих друг на друга художников, как Шамиль Шайдуллин, Зуфар Гимаев, Фарид Якупов, Станислав Слесарский, а также других интересных, самобытных живописцев.

Придя в искусство в послевоенные пятидесятые, для которых свойственно подробное запечатление сюжета, факта, события, Харис Якупов пишет на языке своего времени. Его искусство фигуративно, подробно воспроизводит детали, композиции напоминают театральные мизансцены. Однако в них молодому автору удавалось запечатлеть идейную содержательность эпохи. Уже в 1951 году он добивается небывалого успеха: получает вместе с Лотфуллой Фаттаховым Сталинскую премию третьей степени за картину «Подписание декрета об образовании Татарской АССР». Эта работа вызвала большой общественный резонанс как сюжетом, так и мастерством исполнения. На картине изображен момент подписания Декрета об образовании Татарской АССР, а персонажами выступают председатель ВЦИК М. Калинин, член Революционного военного совета РСФСР И. В. Сталин, председатель СНК В. Ульянов (Ленин), окруженные представителями татарского народа.
В той же живописной манере, но с большим эмоциональным напряжением написана другая, не менее резонансная картина Якупова «Перед приговором (Муса Джалиль)» (1950-1954 гг., Музей изобразительных искусств Республики Татарстан). В лучших традициях социалистического реализма художник запечатлел нравственный подвиг поэта-героя, которого видел своими глазами еще в тридцатые годы будучи подростком.

На протяжении всего творческого пути развивалась живописная манера Якупова. Меняющаяся современность требовала новые художественные формы и новых героев своего времени. Претерпевал изменения и образный мир автора. В 1960-80-е годы манера художника от конкретной зарисовки переходит в более обобщенный, собирательный, монументальный образ. По колориту и особенностям композиции в картинах этого времени более ощутимо национальное своеобразие творческой манеры автора. Главным героем его картин становится обобщенный персонаж своего времени - простой человек, руками которого созидалась новая мирная жизнь. Его герои - это нефтяники республики, строители автогиганта КамАЗ, работники села - доярки, пастухи, комбайнеры. В галерее образов того времени такие работы, как «Сильные люди» (1964), «Золото Татарии» (1974), «Челнинские красавицы» (1975) и многие другие.

Тема войны, открытая Якуповым еще во фронтовых зарисовках, стала сквозной в его творчестве. Глубоко прочувствованы образы картин, посвященных войне. Примером может служить триптих «Полет на свободу» (19641971), посвященный подвигу гвардии старшего лейтенанта, летчика-истребителя, Героя Советского Союза Михаила Петровича Девятаева, который смог совершить побег из концлагеря на угнанном им бомбардировщике. Художник и его герой - почти ровесники, отчасти и поэтому $\mathrm{X}$. Якупов так глубоко прочувствовал тему этого триптиха.

Как окно в прошлое воспринимается исповедальная картина «Художник. Дороги фронтовые» (1985). Это автопортрет, своеобразный взгляд через сорок лет на самого себя и на свою трудную фронтовую молодость.

В наследии Хариса Якупова есть произведение, связывающее его творчество с историей университета. Это большая картина «Казанские студенты. Год 1887» [Татарский энциклопедический словарь, с. 683]. Над ней автор работал 
в течение почти десяти лет. Ее создание было приурочено к столетнему юбилею студенческой сходки, в которой непосредственное участие принимал студент первого курса юридического факультета В. Ульянов. Это полотнопанорама изображает драматическое столкновение администрации университета со студентами, требующими преобразований университетской жизни. Художник с исторической скрупулезностью воспроизвел детали интерьера актового зала и элементы одежды персонажей: портрет императора, люстру, студенческие куртки и опрокинутый венский стул. Интересно отметить, что творческая реконструкция зала, сделанная Харисом Якуповым в конце 1970-х годов, близка к научно восстановленному интерьеру «Императорского актового зала», сделанному значительно позднее уже в нынешнее время.

Еще одна тема достойна внимания - союз искусства и поэзии. Если картина «Перед приговором» была посвящена прежде всего подвигу поэта Мусы Джалиля, то триптих «Памяти Габдуллы Тукая» (2000) предстает как визуальное воплощение в изобразительном искусстве поэтики Тукая. Это рассказ, аллегорически изображающий образный мир поэта.

Последние выставки художника познакомили нас с камерной стороной его творчества. Здесь Харис Якупов предстал талантливым многогранным живописцем-лириком. Перед зрителем прошла анфилада портретных образов. Это родные и близкие художника, друзья и просто современники.

Харис Якупов тонко чувствовал природу. Его натюрморты, изображающие простые вещи, отличаются замечательной маэстрией исполнения.

Если говорить о своеобразии художника, то необходимо отметить, что в его искусстве органично соединились веяния времени и сюжетика с национальной выразительностью. Национальное в искусстве татарского художника Хариса Якупова проявилось прежде всего в декоративности ярких цветовых пятен, происходящих от народного декоративно-прикладного искусства, его склонности к монументальной плоскостности композиции. Персонажи картин художника, точно детали национального костюма, распределяются крупными пятнами по плоскости холста, создавая этим яркое, позитивное образное решение. Именно позитивное звучание творчества является главным содержанием его искусства.

Художник был понят и принят современниками. В истории республики трудно назвать другого деятеля культуры, кто был бы удостоен таким же вниманием. Харис Якупов, кроме уже упомянутых военных наград, был удостоен высшими орденами СССР - орденами Ленина, Дружбы народов, «Знака почета», «За заслуги перед Отечеством» 4-й степени, «За заслуги перед Республикой Татарстан». Кроме Сталинской премии 1951 года, он также был удостоен в 1976 году Государственной премии РСФСР им. И. Е. Репина за картины «Челнинские красавицы» и «Передовые животноводы - пастухи Н. Зиганшин, Ш. и Г. Шакировы». В 1958 году, вновь совместно с Л. Фаттаховым, Х. Якупов получает Республиканскую премию Татарской АССР им. Г. Тукая за иллюстрации к книге татарских народных сказок.

Звания народного художника РСФСР мастер был удостоен в 1963 году, а в 1980 году получил высшее почетное звание страны «Народный художник СССР».

Творческую деятельность Якупов совмещал с активной общественной работой депутата Верховного Совета СССР с 1971 по 1974 годы.

Вся жизнь художника была неразрывно соединена с судьбой страны, ее историей, ценностями и культурой. Все творчество живописца говорит о том, что он достоин своей судьбы и благодарной памяти потомков.

\section{Литература}

Мы все стремились к победе... Из фронтовых альбомов Хариса Якупова. Альбом-каталог. Казань: Заман, 2015. 176 с., ил.

Татарский энциклопедический словарь / под ред. М. Х. Хасанова. Казань: Институт Татарской энциклопедии АН РТ, 1998. 703 с.

Червонная С. М. Харис Якупов. Л.: Художник РСФСР. $160 \mathrm{c}$. 